\title{
Dissecting the Human Nature in Kafka's Metamorphosis
}

\author{
Ravi Kumar Shrestha \\ Lecturer in English, Patan Multiple Campus, \\ Tribhuvan University, Lalitpur, Nepal
}

This paper intends to strengthen the relationship between humans and non-humans. So, it searches human nature in the non-human. Human beings dissect animals or nonhumans in the science lab whereas in the novella 'Metamorphosis', Franz Kafka dissects human nature in the insect after Gregor's metamorphosis. Gallagher writes:

Metamorphosis has ... a variety of meanings ... but with a specific focus oncorporeal transformations of the body that occur either in reality or in theimagination. Rather than use the term imprecisely in the sense of historical orbiographical change, metamorphosis is to be understood in the sense of physicaltransformations of the body from human beings to animals, birds, invertebrates, vegetables or mineral forms or visa versa. This definition will encompassactual, suggested [or] imagined physical transformations of a human being intoanother animal form..." (qtd. In Michael Giovanniello'sThe Will to Change: The Role of Self-consciousness in the Literature of Metamorphosis

The above lines define metamorphosis, which is indeed physical transformation of humans into non-humans. It is used as a powerful literature tool in this paper.

The representation of animals in different genres of literature such as fictionfairytales, fables, short stories and novel, dramas, poetry etc has a long and unforgettable history. They are delineated as an integral part of human life. So, they play an eminent role in various aspects of human life such as food, trade, entertainment and ecological balance. Shivendra B. Kadgaonar writes:

Literature like Jataka, Panchatantra, Hitopadesh shared a wonderful bond between human beings and animal world with their moral implications. From the period of Buddha or before man did respect ecology. Human beings and animals, birds live interdependently and harmoniously. In Buddhist and Jaina art animal depiction is in a large quantity and artistically. Buddhist cave art and sculptures on stupas famous for animal world depiction e.g. caves at Bedsa, Bhaja, Karle, Kanheri, Nasik, Ajanta, Bagh (for painting) and stupas at Barhut Gaya, Amravati, Sanchi etc. After Buddhist art animals, birds were depicted on Hindu temples as vahanas of Gods, Goddesses, as a symbol and also in dwarshakhas or on plinth of temples as a Gajathara, Asvathara etc. (164)

The above lines reflect how the bond between humans and non-humans has been maintained as an essential bond since time immemorial in this natural planet. However, because of anthropocentric nature of humans, the non-humans are being exploited. As a result, the ecology is endangered today. Hence, the maintenance of the nexus between humans and non-humans is a must. 
Franz kafka'sTheMetamorphosis is a master piece of modern literature. It narrates the bizarre tale of GregorSamsa's transformation into a huge insect which is the hybridization of human and animal. This text explores the human feelings and nature in animals and lack of humans' such feelings for non-humans or animals. As a result, the text expresses the alienation and personal quest for meaningful identity and existence of GregorSamsa. This paper is an attempt to open the eyes of so called humans who regard themselves to be superior to the rest of non- humans and who believe that they can be their masters or can exploit any other creatures for their sake. So, this paper raises questions: what will happen to such humans if they find themselves in the dehumanized state of Gregor? What is the cause of Gregor's metamorphosis? What does the human soul in the animal body represent? Does this text value the importance of nexus between humans and non-humans? Is this not the era that academia should value 'The State of Human Animal Studies'? Kenneth Shapiro and Margo Domello argue:

"With the publication of Peter Singer's Animal Liberation (1975) followed by Tom Regan's The Case for Animal Rights(1983), there has been burgeoning interest in animals among academics, animal advocates, and the general public. HAS scholars recognize the lack of scholarly attention given to non-human animals and to the relationship between human and non-human especially in the light of the pervasiveness of animal representations, symbols and stories, as well as the actual presence of animals in human societies and cultures" (1)

The above lines indicate the importance of the state of human-animal studies, for the lack of humanityshown to non-humans is a present burning global issue. In order to prioritize such an issue, this paper has been written. It is divided into twoparts i.e. the two different states of transformed Gregor is explored in kafka'sMetamorphosis: insected/infected (Gergor) human and dissected (Gregor's soul) human soul.

Franz kafka'sMetamorphosis was written in 1992 and published in 1915 when Prague, a European city of Astro-Hungary empirewas highly under the influence of industrialization which had engulfed the entire Europe. Europe had started facing a great uncertainty and exhausting change during the $19^{\text {th }}$ century. So many changes appeared dueto modernization. The modern age replaced the authority of God with the absolutes of science. Even the Enlightenment brought forth new ideas and gave an outlet to intellectual freedom. The major change that modernization brought was the industrial revolution which drastically transformed the economics and social hierarchies of Europe. On the one hand, industrialization opened the doors of job opportunities to people. On the other hand, due to it, science and technology was used. The use of machines and increase in commercial activities affected the lives of family. Europeans startedstruggling for identity. It started fragmenting the society. So, they suffered from anxiety, alienation and a state of hopelessness. GergorSamsa has been delineated as a protagonist in Metamorphosis who is highly infected by industrialization. When he awoke one morning from uneasy dream, he found himself transformed into a gigantic insect. Although he has the body of beetle, he has the mind and memories of a human. He realized that his train goes at five. So, he had to be ready. But as he became an insect, he couldn'topen the door at once acting, as a human. It was getting late. His parents and his sister started knocking at the door. His role as a bread winner for the whole 
family working as a travelling salesman in the story proves his pivotal role in the family. Despite his reluctance for the job, he competed with others for running the family. Thus, he had fulfilled his responsibilities to his family, employer and community. However, once industrial activities infected him, he was taken other way.Kafka writes:

"I mention this only in passing neglecting your business duties in an incredible fashions. I'm speaking here in the name of your parents and of your chief and I beg you quite seriously to give an immediate and precise explanation"(371)

These lines clearly reveal that a modern worker is not better than that of a machine or an animal. They indicate how along with industrialization humans have lost human values, existence and identity. The chief clerk's indifference to Gregor is obvious. Apparently, Gregor is accused of being insincere, but he is suffering in the room being an insect because of metamorphosis.

The Metamorphosis demonstrates how the demarcation line between humans and non-humans is created. The difference between them on the basis of body is shown. Before Gregor transformed into a bug, he was the centre of the family. However,after his metamorphosis, he was solely judged by his insect body. The outlook of not only the society but also his whole family changed all of a sudden. His insect body disgusted everyone. The head clerk fled the apartment, his mother whom he badly needed in such a critical state even rejected him, his father tried to kill him, his sister eventually overlooked him, the cleaning lady abused him and tenants also hated him. All of their changed attitudes reflect human's indifference towards non-human. Jay David Bolter argues, "Above all, posthumanism opposes the essentialism that it finds in the traditional interpretive practices of the humanities"(7). The Metamorphosis demonstrates clearly how humanity in humans is dead for the sake of non-humans and posthumanists find it in this novella.

Kafka wrote this book after the industrial revolution. He was a keen observer of horrors of industrial revolution. He was aware of its fatal consequences upon humans. Therefore, there is a connection between the insect form of Gregor and the transformation of workers into machines. In other words, the industrial revolution created factories which use humans as nothing more than mere bugs. In this novella, Gregor is doubly victimized. Firstly, it suggests that he is reduced to a bug by the modern industrial world that treats him like a machine or a bug. Secondly, his family and society also used him like a machine. None of them seem to have an emotional bond of love with him. The dehumanized form of Gregor in the form of the bug even reveals the suppressed animality of humans. Besides, it reflects the infection of modern society. In this context, Christina Gerhardt writes, “ Thesuppredanimality of humans, Adorno argues, is a symptom of modern society; its antidote is sympathy with the suffering of animals".(169)

The insect body symbolizes a fatal consequence of rationalization caused by modernity, which is indeed alienation. The head clerk's indifference towards him is the indication of the company's suppressive and exploitative attitudes towards workers. In the same way, his family's indifference really hurt him. Kafka writes that when his mother pointing towards his room said,

'Shut the door now, Grete,' and he was again left in darkness(389). It reveals that even his family was not as they were before Gregor's metamorphosis. S.L.Dhoni argues: 
Max Weber defined modernity as rationalization. Georg Simmel, a contemporary,compatriot, and friend of Weber's had a similar opinion. Both theorists pointed out that the benefits of rationalization and industrialization, embodied in science and technology, were offset by the environment excess that scientific and technological 'progress' allows.Furthermore, modern life produces a great deal of alienation and anomic among individuals.(73)

The above lines show how Max Weber and Georg Simmel point out the gloomy side of modernity, which is actually the hegemony of rationality in human life. The same thing happens to the dehumanized Gregor, whom humans treat only as an animal rather than a human.

In today's $21^{\text {st }}$ century, animals and humans are dissected in the science lab, whereas Kafka's Metamorphosis dissects human soul in the animal body.So, this paper explores the human nature in the non-human body. In this human-centered world, humans lack feelings for non-humans, in whom humans hardly think there is even the soul or feelings. Along with people's growing concern for ecological balance between humans and non-humans, posthumanists or ecocritics blame anthropocentric nature of humans to bypass the existence of animal nature or animal soul. In this context, however,Metamorphosis has done the dissection of human soul successfully.Kyleen Oldham claims, " TheMetamorphosis states the idea of being a center of society and the center of family being altered" (153). Gregor transformed into a bug, but he had the human soul. Therefore, he had the human nature, which judged how people round him changed because of his non-human body. The novella explores how along with the change of Gregor's body the nature of his family and society changed. This new body allowed him to see and understand about humans and human nature that he had failed to do as a human. Hence, non-human body seems to have been a great advantage for him to understand the human nature. Kafka writes, "just what I have been telling you, but you women would never listen,"(386). It reveals how Gregor had failed to understand his father who had kept grudge towards him although he was the breadwinner for the whole family. His father seems to have been expecting and waiting for Gregor's worst condition. So, Kafka seems to reflect a belief that the more generous and selfless one is, the worse one is treated.

The Metamorphosis explores the pathetic plight of the tortured and devastated human soul in the non-human body. The mental turmoil of Gregor after his metamorphosis through the ill-treatment of his sister, father and society is very painful for him. He was hurt by a cut glass and his father's apple hit him and sank in his body, however, he thought for thewelfare of his family and others. Kafka writes:

Gregor hardly slept at all by day. He was often haunted by the idea that the next time the door opened he would take the family's affairs in hand again just as he used to do; once more, after this long interval, there appeared in his thoughts the figures of the chief and the chief clerk, the commercial travelers and the apprentices, the porter who was so dull-witted, two or three friends in other firms, a chambermaid in one of the rural hotels, a sweet and fleeting memory, a cashier in a millner's shop whom he had wooed earnestly....(389) 
The above lines reveal how non-humans penetrate into the psyche of humans and feel for humans whereas humans become indifferent to non-humans. In spite of having a bug body and facing a social stigma from nearest and dearest ones, he became ready to help them in whatever way he could .Doesn't it symbolize the heroic nature of non-humans that is misunderstood and misinterpreted by demonic nature of so called humans in the world?

The Metamorphosis minutely presents the two worlds side by side: the world of the humans and the world of non-humans. On the one hand, it explores the nature of humans and their exploitative and negative attitudes towards non-humans in the human world. Gregor's family's and society's attitudes towards the insect Gregor reveal it. On the other hand, the novella explores the nature of non-humans and their attitudes towards humans through the human soul in the non-human body. For this, Kafka used metamorphosis as a powerful literary tool and delineated Gregor as a mouthpiece for the criticism of human nature. Firstly, Gregor as an insect but having the human soul judges humans to be very selfish, exploitative and inconsiderate. Secondly, Gregor as an insect and representing the entire animal world tends to give a powerful message to readers that humans should realize that non-human animals feel as insectedGregordoes. In this context, Marion Gymnich and Alexandre Segao Costa argue, "The use of the motif of human-animal transformation not only criticizes certain aspects of the colonial situation; it is also an instrument for expressing criticism of human nature in general" (82). Thus, Gregor's bug body reveals the real human nature. At the same time, one major objective of such metamorphosis is to strengthen the bond between animals and humans. Marion Gymnich and Alexandre Segao Costa write, " The literary motif of human-animal metamorphosis, for example, may challenge the rigid demarcations between human beings and animals which are prevalent in the society..."(72).

Kafka beautifully and artistically reveals the heroic nature of human in the bug body, which is likely to enable human beings feel for non-human animals. After his metamorphosis he didn't suffer only from the infected bodily pain caused by his father but also from mental grief due to alienation and lack of respectand care from people around him. Gradually, he observed different changes appearing in the family. He found how his father had lied to him regarding actual financial position of the family and his own ability to work. He realized that the family whom he had expected to be unable to exist without him began to struggle. He found himself to be a great obstacle for his family. Kafka explains:

True, his whole body was aching, but it seemed that the pain was gradually growing less and would finally pass away. The rotting apple in his back and the inflamed area around it, all covered with soft dust,already hardly troubled him. He thought of his family with tenderness and love. The decision that he must disappear was one that he held to even more strongly that his sister, if that were possible. (396)

Apparently, he seems to have been killed by the apple as an object. Symbolically, the apple indicates knowledge. When he was hurt by the apple, he had the knowledge of his family, society, and the world. What he could not understand being a human, he did being a bug.He felt that he was useless and troublesome for his family and they wanted to get rid of him. Having had this knowledge he thought of sacrificing his life for the betterment of his family and he did so ending his life at 3 o'clock in the morning. Doesn't it reveal the heroic 
nature of human soul inherent in the non-human body? If so, doesn't it mean non-humans can also think of sacrificing for the existence of humans? Then shouldn't humans be concerned about existence of non-humans?

The Metamorphosis symbolizes the migration of soul. Different mythologies support it, too. Hindu Mythology not only supports it but also highlights the ten avatars or incarnations of Lord Vishnu. Among these ten avatars, the first three avatars are Matsya, Kurma and Varaha, which reveals clearly how the divine soul migrated into the body of animals such as Fish, Tortoise and Wild boar. The incarnated form of Lord Vishnu in the form of animal is believed to have been for the liberation of the victimized humans or nonhumans in the world whenever there was imbalance in nature. Hence, the Dash avatar concept, on the one hand, seems to convey the message to humans that non-human bodies may have the divine soul i.e. God manifests through non-humans, too. On the other hand the Dash avatar concept seems to give a warning and threat to humans that they shouldn't be indifferent to non-humans. Nilanjana Das writes critically, "Dash avatar is a Hindu mythological concept. This concept in many ways is related to physical environment" (30).The fouth avatar is Narsinghi.e.divine soul in a hybrid body man-lion and in other six avatars divine soul in human bodies. Doesn't it indicate that in one way evolution of humans started from animals? If so, why are they exploited and cruelly treated? Marion Gymnich and Alexandre Segao Costa have given the example of Ovid's Metamorphoses. They argue, "The ecological idea that all living beings are connected with each other is rounded off by picking up the idea of a migration of souls, which can be found in Ovid's Metamorphoses in the context of human-animal transformation"(81).

Thus, this paper blends dichotomies between humans and non-humans, and between society and nature dissecting the human nature in the insect body. This paper has been mainly divided into two parts. Firstly, the protagonist's(Gregor's) insect body helps him know what he had failed to do as a human. Secondly, the tragic state of the tortured human soul in the animal body indicates the human nature and hence it is likely to strengthen the bond between human and non-human. Such a paper is likely to enable humans to preserve the fragile ecosystem realizing that even non-humans may also feel as humans as they may have souls like those of humans. Therefore, this paper discourages people from being anthropocentric. Instead it is likely to encourage people to be nature lovers, ecocritics and post-humanists making a strong nexus between animals and humans for the welfare of the earth.

\section{Works Cited}

Bolter, Jay David. "Posthumanism.”

Das, Nilanjana. “ Environmental Interpretation of Dash avatar, Changing Use of Dash avatar Cards and its Impact on Society and Space". Researchgate. https:// www.researchgate.net/publican/272106588.

Demello, Margo and Kenneth Shapiro. " The State of Human-Animals Studies”

Doshi, S.L. " Theories of Modernity." Modernity, postmodernity and Neo-Sociological Theories.Rawat Publications, New Delhi, 2006.pp 57-92 
Geovanniello, Michael. "The Will to change : The Role of Self-consciousness in the Literature of Metamorphosis" Cuny Academic works, 2015.

Gerhardt, Christina, “ The Ethics of Animals in Adorno and Kafka.” New German Critique, No.97. AdornoEthics, 2006, Winter, pp.159-178.

Gymnnich, Marion and Alexandre Sagao Costa. "Of Humans, Pigs, Fish and Aps: The Literary Motif of Human-Animal Metamorphoses and its Multiple Functions in Contemporary Fiction", L'Espirit Creature,Volume. 46.No.2.Literature and Ecology, 2006(Summer), pp.68-88

Kadgaonkar,Shivendra B. "The Role of Animals and Birds in Ancient Indian Art and Culture". Bulletin of the Deccan College Research Institute. Vol. 68/69. Pp.163-165

Kafka, Franz. "The Metamorphosis". An Introduction to Fiction, Poetry and Drama by Ann Charters and Samuel Charters, Bedford Books Publication, London, 1997.pp.365-399. 